\title{
Optimism, self-esteem and personality: adaptation and validation of the Brazilian Version Of The Revised Life Orientation Test (LOT-R)
}

\author{
Micheline Roat Bastianello - Universidade Federal do Rio Grande do Sul, Porto Alegre, Brasil \\ Juliana Cerentini Pacico - Universidade Federal do Rio Grande do Sul, Porto Alegre, Brasil \\ Claudio Simon Hutz - Universidade Federal do Rio Grande do Sul, Porto Alegre, Brasil
}

\begin{abstract}
Optimism can be defined in terms of positive and negative expectations regarding future life events. The aims of this study were to adapt and validate the Revised Life Orientation Test (LOT-R) for the Brazilian population, verify its psychometric characteristics, assess whether there are gender differences, and verify its relationships with self-esteem and personality. The participants were 844 university students from two public universities in the southern of Brazil, which answered the following tests: LOT-R, Rosenberg Self-Esteem Scale and Baterial Fatorial de Personalidade (BFP). Factor analysis extracted a single factor, corroborating the findings of the original scale and indicating that optimism and pessimism are probably polar opposites of a single continuum. The results showed positive correlation between self-esteem and optimism in life orientation, and negative correlation between optimism and neuroticism. In conclusion, the Brazilian version of the LOT-R is an instrument that presents appropriate psychometric characteristics and that is ready for use in the Brazilian population.
\end{abstract}

Keywords: Optimism; LOT-R; Self-esteem; Personality; Positive Psychology.

Otimismo, autoestima e personalidade: estudos de adaptação e validação brasileira do Revised Life Orientation Test (LOT-R)

\begin{abstract}
Resumo
O otimismo pode ser definido em termos de expectativas positivas e negativas com relação a eventos de vida futuros. Os objetivos deste estudo foram adaptar e validar o Revised Life Orientation Test (LOT-R) para a população brasileira, verificar suas características psicométricas e avaliar se existem diferenças de sexo. Também investigou as correlações entre otimismo, autoestima e personalidade. O LOT-R foi traduzido e submetido a uma backtranslation. Participaram do estudo 844 universitários de duas universidades públicas do sul do Brasil, que responderam aos seguintes instrumentos: LOT-R, Escala de Autoestima de Rosenberg e Bateria Fatorial de Personalidade (BFP). análise fatorial extraiu um único fator, corroborando os achados da escala original e indicando que otimismo e pessimismo são, provavelmente, polos opostos de um mesmo continuum. Os resultados demonstram correlação positiva entre autoestima e otimismo na orientação para a vida, e correlação negativa entre otimismo e neuroticismo. Conclui-se que a versão da LOT-R apresenta características psicométricas adequadas e o instrumento encontra-se pronto para ser utilizado com a população brasileira.

Palavras-chave: Otimismo; LOT-R; Autoestima; Personalidade; Psicologia Positiva.
\end{abstract}

Optimismo, autoestima y personalidad: estudios de adaptación y validación versión brasileña del revised life orientation test (LOT-R)

\section{Resumen}

El optimismo puede ser definido en términos de expectativas positivas y negativas con respecto a acontecimientos de vida futuros. Los objetivos de este estudio han sido adaptar y validar el Revised Life Orientation Test (LOT-R) para la población brasileña, comprobar sus características psicométricas y evaluar si hay diferencias de sexo. También se investigó las correlaciones entre el optimismo, la autoestima y la personalidad. El LOT-R fue traducido y sometido a una backtranslation. Los participantes fueron 844 estudiantes universitarios de dos universidades públicas del sur de Brasil, que contestaron los siguientes instrumentos: LOTR, Rosenberg Self-esteem Scale y Bateria Fatorial de Personalidade (BFP). El análisis factorial extrae un solo factor, lo que corrobora los resultados de la escala original e indica que el optimismo y el pesimismo son, probablemente, polos opuestos de un mismo continuum. Los resultados demuestran una correlación positiva entre la autoestima y el optimismo en la orientación a la vida, y una correlación negativa entre el optimismo y el neuroticismo. Llegamos a la conclusión de que la versión de la LOT-R tiene características psicométricas adecuadas y el instrumento está listo para su uso con la población brasileña.

Palabras-clave: Optimismo; LOT-R; Autoestima; Personalidad; Psicología positiva.

\section{Introduction}

Optimism can be defined as a stable personality trait related to positive expectations regarding future events.
Optimists are people who expect that good things will happen to them, while pessimists expect bad things to happen (Scheier \& Carver, 1985). Thus, the definition of optimism is supported by positive expectations about 
future outcomes. It presumes that when a goal is important, the person will act to reach the desired goal, hoping for positive results (Scheier \& Carver, 1985, 1993).

By anchoring the definition of optimism and pessimism in expectations for the future, Scheier and Carver (1985) demonstrated that the roots of these constructs are theoretical and empirical studies on motivations and how they are expressed in human behavior expectancy-value models of motivation. This model explores the motivations underlying behaviors, admitting that they are organized around two key elements: goals and expectations.

Goals are actions or states that are desirable or undesirable by people. Thus, it is logical to think that people seek to engage their efforts to achieve the goals that they consider important. The more valuable and meaningful is a goal, the greater the motivation to act (Carver \& Scheier, 2003). The second element of the theory, expectation, is understood as a sense of conviction or uncertainty about achieving a goal. Efforts will be made towards the goal only if the person is confident enough concerning the expected outcomes (Scheier, Carver, \& Bridges, 2001).

Thus, people who have an optimistic orientation towards life tend do have positive expectations regarding the future, to realize that the desired is possible and to persist in their efforts. Pessimists, in turn, have negative expectations, strive less, tend to become passive and give up more easily on their goals (Scheier \& Carver, 1985).

Empirical evidence shows that optimism and pessimism have significant effects on physical and mental well-being (Carver, Scheier, \& Segerstrom, 2010; Scheier, Carver, \& Bridges, 2001). Optimism is associated to higher academic performance (Aspinwall \& Taylor, 1992), better professional performance (Long, 1993), better recovery from coronary surgeries (Fitzgerald, Tennen, Affleck, \& Pransky, 1993) and bone marrow transplants (Curbow, Somerfield, Baker, Wingard, \& Legro, 1993), as well as better coping with diseases such as cancer (Carver et al., 1993) and AIDS (Taylor, Kemeny, Aspinwall, Schneider, Rodriguez, \& Herbert, 1992). Within this context, optimism is seen as a behavioral strategy that allows people to be happier, more successful and healthier in their lives (Lopez \& Snyder, 2003).

However, there are few studies on the etiology of dispositional optimism and pessimism. Hereditary factors are regarded as being responsible for $25 \%$ of the variance for optimism-pessimism in heterozygous twins (Plomin et al., 1992). Constitutional factors such as a difficult temperament in childhood are also identified as predictors of a pessimistic attitude in adult life (Heinonen, Räikkönen, \& Keltikangas-Järvinen, 2005). Other studies suggest that a positive family environment and authoritative parenting styles during childhood are associated with high scores on selfesteem and optimism in young adults (Jackson, Pratt, Hunsberger, \& Pancer, 2005).

To assess individual differences in optimism and pessimism, Scheier and Carver (1985) developed the Life Orientation Test (LOT). Several studies performed with this instrument pointed to controversial results regarding the construct unidimensionality and also for coincidences with neuroticism, trait anxiety, self-mastery and self-esteem (Chang, D'Zurilla, \& Maydeu-Olivares, 1994; Dember \& Brooks, 1989; Smith, Pope, Rhodewalt, \& Poulton, 1989). Due to such criticisms, Scheier, Carver and Bridges (1994) revised the instrument, removing items that did not focus explicitly in expectations regarding the future. In the new version, the Revised Life Orientation Test (LOT-R), the items measuring positive and negative expectations are more strongly linked.

LOT-R has strong relationships with predictive markers of results for life orientation, which is consisting with the idea of being a good instrument to measure optimism in relation to constructs such as selfesteem and personality factors (Carver \& Scheier, 1999, 2002). Carver and Scheier (1999) suggest that optimism is partly learned from previous experiences of success and failure. From this point of view, the explanation for the association between self-esteem and optimism may be the potential role of self-esteem in increasing the possibility of success experiences and overcoming difficulties despite adversities.

Self-esteem is the sense of self-worth that the individual bears, and the confidence that he will be particularly more accepted than rejected, and that he is not a failure in life (Coopersmith, 1967; Crocker \& Major, 1989; Rosenberg, 1965). This sense involves positive and negative affects, linking self-esteem conceptually to optimism-pessimism (Smith, Pope, Rhodewalt, \& Poulton, 1989). Studies suggest that self-esteem increases motivation (Aspinwall \& Taylor, 1992), is related to higher overall persistence in targeted goals (Di Paula \& Campbell, 2002) and, in adolescents, it is a strong predictor of optimistic or pessimistic orientation in adult life (Heinonen, Raikkonen, \& Keltikangas-Jarvinen, 2005). In addition to increasing the probability of success, high self-esteem can also reduce the effect of occasional failure, and thus the 
risk of developing high levels of pessimism (Campbell, Chew, \& Scratchley, 1991).

In a study of subjective well-being, Myers and Diener (1995) observed that happy people presented four consistent traits: self-esteem, optimism, sense of self-control and extroversion (personality factor). These data support the idea that personality factors such as extroversion and sociability, as well as positive feelings about oneself and feeling of self-control contribute for people to present a greater sense of confidence about positive future events (Lyubomirsky, Tkach, \& Dimatteo, 2006).

Other studies suggest that pessimism is associated with Neuroticism and negative affects, while optimism is related to extroversion and positive affects (Marshall, Wortman, Kusulas, Hervig, \& Vickers, 1992). However, there are no studies that correlate optimism and personality in the personality Five-Factor Model (FFM), through the Bateria Fatorial de Personalidade (BFP).

The FFM model or Big Five was originated in the analysis of language used to describe people. The use of adjectives of natural language as describers of traits has been regarded as the best strategy to identify factors that enable a better understanding of personality characteristics (Briggs, 1992). The discovery of this method is an empirical generalization independently replicated numerous times.

In Brazil, based on the Five-Factor Model, researchers developed the Bateria Fatorial de Personalidade (BFP - Nunes, Hutz, \& Nunes, 2010), a battery of tests that includes the dimensions of neuroticism, extraversion, agreeableness, conscientiousness and openness to experience. It appears that, despite the considerable volume of studies on optimism, there are few studies correlating this construct with personality. Furthermore, there are no Brazilian studies on optimism, self-esteem and personality.

The aim of this study was to adapt and validate the Revised Life Orientation Test (LOT-R), to verify its psychometric properties and to assess whether there are sex differences between genders. It also aimed to investigate the correlations between optimism, selfesteem and personality in the FFM.

\section{Method}

\section{Participants}

The study included 844 undergraduate students from two public universities in southern Brazil. Students were from various graduation-courses: Business
Administration, Law, Electrical Engineering, Physics, Pharmacy, Biomedicine, Biology, Nursing, Veterinary Medicine, Physiotherapy, Nutrition, Speech Pathology, Psychology, Public Relations, and Languages. The ages of the students ranged from 17 and 36 years, with mean of 21 years $(\mathrm{SD}=3.2)$. Among these, $57 \%$ were women and $43 \%$ men. The sample was chosen by convenience and participation was voluntary.

\section{Instruments}

First, participants completed a socio-demographic data sheet in order to characterize the sample. Then, the Brazilian version of the LOT-R was administered aiming to adapt and validate the test, determine its psychometric characteristics and to evaluate gender differences. They also responded the Rosenberg SelfEsteem Scale and the Bateria Fatorial de Personalidade $(B F P)$ in order to investigate the correlations between optimism, self-esteem, and personality traits in the FFM.

\section{Revised Life Orientation Test (LOT-R)}

The LOT-R (Scheier, Carver, \& Bridges, 1994) is a test developed to measure self-reported dispositional optimism, being a reduced and revised version of the Life Orientation Test - LOT (Scheier \& Carver, 1985). The test includes 10 items: three statements about optimism (items 1, 4 and 10), three on pessimism (items 3, 7 and 9) and four distractor items (2, 5, 6, 8) whose scores are not computed. Subjects answer the statements indicating their level of agreement on a five-point Likert scale, ranging from strongly disagree to strongly agree. The negative scores on the test need to be inverted for the statistical analysis, so that values close to five always indicate a higher degree of optimistic expectations of the individual. LOT-R has good internal consistency (alpha coefficient ranging from .70 to .80) and their correlations test-retest are from .68 to .79 for intervals of four to 28 months (Scheier, Carver, \& Bridges, 1994).

\section{Baterial Fatorial de Personalidade (BFP)}

The Bateria Fatorial de Personalidade (BFP) is a psychological instrument designed for the assessment of personality based on the Five-Factor Model, which includes the following dimensions: Neuroticism, Extroversion, Agreeableness, Conscientiousness and Openness. The battery was developed in Brazil by Nunes, Hutz and Nunes (2010), considering the following aspects: language, cultural values, regional diversity, and specificity of Brazilian clinical manifestations. BFP was based on items of scales previously 
developed that assess the five factors individually. Specifically, were used items from the Neuroticism Factor Scale (EFN), Extroversion Factor Scale (EFE), Agreeableness Factor Scale (EFS), Conscientiousness Factor Scale (EFR) and Openness Factor Scale (EFA) (Hutz, Nunes, Silveira, Serra, Anton, \& Wieczorek, 1998). Most of its aspects present good or very good internal consistency, with alpha coefficient of .89 for Neuroticism, .84 for Extroversion, .85 for Agreeableness, .83 for Conscientiouness and .74 for Openness. The scale includes 126 items, which must be answered according to a Likert-type scale ranging from zero to seven, indicating increasing rates of identification with the answered item.

\section{Rosenberg Self-Esteem Scale}

The Rosenberg Self-Esteem Scale is a self-report scale to evaluate self-esteem through a single dimension. This scale was adapted and validated in Brazil by Hutz and Zanon (2011). It includes 10 multiplechoice questions that make the respondents reflect on their satisfaction with themselves, their qualities and abilities, self-worth, pride and self-respect, positive attitude about themselves, feelings of worthlessness, and feelings of failure. Participants answer each of the 10 statements in a Likert-type scale of four points, indicating the degree of agreement (maximum four) and disagreement (minimum one) with the item described. The higher the score was, the higher the individual's self-esteem. The scale has presented constant reliability rates, acceptable for use in research (alpha coefficient .82).

\section{Procedures}

\section{Translation and adaptation of the LOT-R}

The proposed procedure for the translation and adaptation of the LOT-R consisted, primarily, in translating the test into Brazilian Portuguese. This procedure was completed by a Brazilian independent bilingual translator (Anastasia \& Urbina, 2000). Then, the next step was to perform a back-translation from Portuguese into English by a second bilingual translator, from American nationality. This was a blind procedure, so that the translator did not have access to the original version of the test. After the back-translation, three bilingual judges compared the back-translation with the original English version. They concluded that the translation was adequate. The following step was to administer the test in a pilot sample of 15 college students in order to analyze the integrability of the sentences (Pasquali, 2000). Participants were asked to read and report, individually, what they understood about each statement. Based on the quality and the unanimity of the answers, the students had some difficulty in understanding item 1 , so one more statement about optimism was added to the test (number 11). After the conclusion of the procedure, the test was administered to the sample of college students described above. Data analysis showed a correlation of .50 between items 1 and 11, indicating the semantic similarity of items. It was observed that item 11 presented greater correlation with the other items and with the total score, so we chose to replace item 1 with item 11 and kept the test with a total of 10 items as in the original version.

\section{Data collection}

For data collection, besides the LOT-R, the Rosenberg Self-Esteem Scale and the Bateria Fatorial de Personalidade (BFP) were also administered, as previously described in the Instruments Section. The collection was made collectively in the classroom, by two researchers. The researchers conducted a rapport presentation about the goals and the importance of the students' participation. Students were informed about the anonymity of participation, its voluntary nature, as well as the possibility of withdrawal at any time. They were also informed about the confidentiality of the data. Only those wishing to participate signed the Informed Consent Term (TCLE) and answered the instruments. After the signature, the students were asked to read the instruments carefully and to answer according to their opinions as sincerely as possible. Data collection was performed in a single session for each group of students and the total time used for the experiment was approximately 40 minutes.

This study was conducted according to the Guidelines and Rules of Research involving Human Beings (Resolution 196/96 of the Brazilian National Health Council). The research project was approved by Ethics in Research Committee (UFRGS), accredited to the National Commission for Ethics in Research (CONEP), Ministry of Health.

\section{Results}

To evaluate the factor structure of LOT-R were conducted a component analysis by the method of 
extraction eigenvalues greater than one, that was of 3.06 and explained $51 \%$ of the total variance (see Figure 1). The results of the factor analysis showed a KMO index of .82 and the result of the Bartlett Sphericity test was significant $(p<0.001)$.

Items presented communalities between .38 and .59 and factor loadings between .62 and .76 (see Table 1). Alpha coefficient of the test was .80 indicating that the LOT-R had an adequate level of internal consistency.

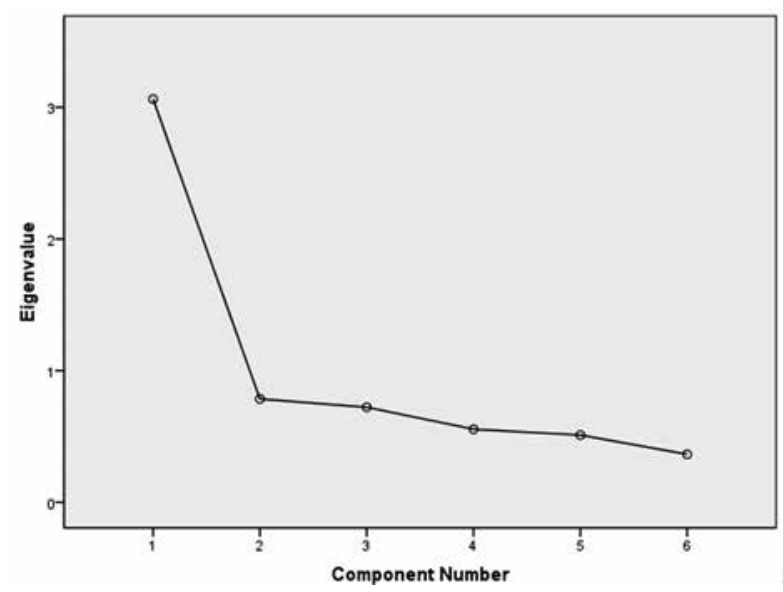

Figure 1. Scree plot of the LOT-R fatorial analyses

Table 1. LOT-R fatorial analyses

\begin{tabular}{lc}
\hline Items & Factor Loadings \\
\hline $\begin{array}{l}\text { 1) Diante de dificuldades, acho } \\
\text { que tudo vai dar certo. }\end{array}$ & 0.67 \\
3) Se alguma coisa pode dar & 0.62 \\
errado comigo, com certeza vai & \\
dar errado. & \\
4) Eu sou sempre otimista com & 0.70 \\
relação ao meu futuro. & \\
7) Em geral, eu não espero que & 0.76 \\
as coisas vão dar certo para \\
mim. \\
$\begin{array}{l}\text { 9) Eu não espero que coisas } \\
\text { boas aconteçam comigo. } \\
\text { 10) Em geral, eu espero que } \\
\text { aconteçam mais coisas boas do } \\
\text { que ruins para mim. }\end{array}$ \\
\hline
\end{tabular}

Note: Items 3, 7 e 9 should be inverted for the statistical analysis. Items 2, 5, 6 e 8 are distractors whose scores are not computed.
It was performed a Student $t$ test to assess possible differences in the means of optimism among men $(\mathrm{M}=23.6 ; \mathrm{SD}=4.63)$ and women $(\mathrm{M}=23.5 ; \mathrm{SD}=4.75)$. There were no significant differences between genders $t(834)=0.53, p>0.95$. Consequently, standards were produced for both sexes together. The standards are shown in Table 2.

Table 3 presents the means, standard deviations and alphas's coefficient of optimism, self-esteem and personality factors. In this study, all variables presented alpha coefficient similar to the original tests.

To assess the relationship between optimism, self-esteem and personality, Pearson correlations were

Table 2. Optimism in men and women (LOT-R)

\begin{tabular}{ccc}
\hline Percentile & Raw score & Standard score $(\mathrm{T})$ \\
\hline 5 & 14 & 32 \\
10 & 17 & 36 \\
15 & 18 & 38 \\
20 & 20 & 40 \\
25 & 21 & 45 \\
35 & 22 & 48 \\
45 & 24 & 50 \\
55 & 25 & 53 \\
65 & 26 & 55 \\
75 & 27 & 57 \\
85 & 28 & 59 \\
95 & 30 & 63 \\
$M$ & 23.5 & \\
$D P$ & 4.7 & \\
\hline
\end{tabular}

Table 3. Optimism, self-esteem and personality descriptive analyses

\begin{tabular}{lccc}
\hline Variables & $M$ & $D P$ & $\begin{array}{c}\text { Cronbach's } \\
\text { alpha }\end{array}$ \\
\hline 1.Optimism (LOT-R) & 23.6 & 4.7 & 0.80 \\
2.Self-esteem & 32.5 & 4.7 & 0.85 \\
3.Neuroticism & 3.3 & 0.83 & 0.87 \\
4.Extroversion & 4.2 & 0.87 & 0.80 \\
5.Agreableness & 5.0 & 0.75 & 0.87 \\
6.Conscientiousness & 4.7 & 0.74 & 0.88 \\
7.Openness & 4.5 & 0.75 & 0.78 \\
\hline
\end{tabular}


Table 4. Correlations among optimism (LOT-R), self-esteem and personality

\begin{tabular}{llllllll}
\hline Variables & $(1)$ & $(2)$ & $(3)$ & $(4)$ & $(5)$ & $(6)$ & $(7)$ \\
\hline 1.Optimism (LOT-R) & - & & & & & & \\
2.Self-esteem & .66 & - & & & & & \\
3.Neuroticism & -.45 & -.66 & - & & & & \\
4.Extroversion & .30 & .37 & -.24 & - & & & \\
5.Agreableness & .31 & .26 & -.31 & .05 & - &. & \\
6.Conscientiousness & .09 & .19 & -.21 & .01 & .24 & - & - \\
7.Openness & $.02^{*}$ & $-.03^{*}$ & -.08 & .34 & -.02 & -.01 & - \\
\hline
\end{tabular}

Note:* significant correlations $(\mathrm{p}<.05)$, all other correlations are significant at $(\mathrm{p}<.01)$

Table 5. Regression Model for Optimism (LOT-R) stepwise

\begin{tabular}{lllll}
\hline Predicted variables & $B$ & Beta & $p<$ & $\mathrm{R}^{2}$ \\
\hline Neuroticism & -1.9 & -0.34 & 0.001 & 0.20 \\
Extroversion & 1.1 & 0.20 & 0.001 & 0.24 \\
Agreableness & 1.2 & 0.19 & 0.001 & 0.28 \\
\hline
\end{tabular}

Note: $F=56.4 ; p<0.001$.

Table 6. Regression Model for self-esteem - stepwise

\begin{tabular}{lllll}
\hline Predicted variables & $B$ & Beta & $p<$ & $\mathrm{R}^{2}$ \\
\hline Neuroticism & -3.38 & -.60 & .001 & .44 \\
Extroversion & .96 & .18 & .003 & .47 \\
\hline
\end{tabular}

Note: $F=73.5 ; p<0.001$.

performed. As it is shown in Table 4, there were negative and moderate correlations between optimism and self-esteem with Neuroticism.

To assess how much variance the personality traits predict on self-esteem and optimism, two multiple regression analysis were performed. Optimism and self-esteem were dependent variables, and Neuroticism, Extroversion, Agreeableness, Conscientiouness and Openness as predictor variables. Tables 5 and 6 present the models derived from the analyses.

\section{Discussion}

The results obtained showed that the LOT-R presented a unidimensional structure. The presence of a single factor explained $51 \%$ of the total variance of the data, which is consistent with the findings of the original study by Scheier, Carver and Bridges (1994). This supports the idea that optimism and pessimism are opposite poles of the same dimension (Laranjeira, 2008; Scheier, Carver \& Bridges, 1994; Trottier, Mageau, Trudel, \& Halliwell, 2008).

The dimensionality of the LOT-R is a very controversial issue in studies on optimism and pessimism. Factorial analysis in different studies usually indicate two distinct elements, one composed by items written in the positive direction and another in the negative direction (Herzberg, Glaesmer, \& Hoyer, 2006; Marshall, Wortman, Kusulas, Herving, \& Vickers, 1992; Scheier \& Carver, 1985; Vautier, \& Raufaste, 2006). The identification of these two factors may be understood as a methodological problem; however, it may be a conceptual issue. Are optimism and pessimism opposite poles of a single dimension or are they two independent dimensions that are correlated?

While revising the LOT original test, Scheier, Carver and Bridges (1994) observed that two items from the positive subset were not explicitly focused on expectations as were the remainder of the items. These two items were discarded, so the items in the LOT-R are more highly intecorrelated. This measure enabled the items of the revised test to be loaded on a single factor.

Given that studies performed after the revision of the instrument continue to indicate controversial results (Lyrakos, Damigos, Mavreas, Georgia, \& Dimoliatis, 2010; Vera-Villarroel, Córdova-Rubio, \& Celis-Atenas, 2009), one can assume that the problem of the dimensionality involves an underlying conceptual issue. There seems to be one kind of optimism guided to the attainment of desirable goals and another related to the avoidance of threats. For each of these constructs there 
may be a pessimism corresponding construct (Carver, Lehman, \& Antoni, 2003).

This is a complex issue to which there is still no clear solution. The empirical findings of this study support the idea that optimism and pessimism are opposite poles of the same continuum, but stresses the importance of further research to explore these constructs conceptually.

The LOT-R presented adequate psychometric characteristics in the present study. Alpha coefficient was .80 , a similar result to the one found in the North-American version $(\alpha=0.78)$ (Scheier, Carver, \& Bridges, 1994).

There were no differences among men and women regarding optimism. This piece of data suggests that gender is probably not a determining factor for the positive and negative expectations of people regarding future events.

When optimism and self-esteem were associated to personality factors, there were moderate and negative correlations with Neuroticism in the first two constructs. This means that, for instance, the lower the level of impairment and emotional instability of the person, the higher the degree of positive expectations regarding future events and the higher the self-esteem. Therefore, individuals with low scores on optimism and self-esteem tend to have high scores on Neuroticism, i.e., when they experience intense emotional pain, excessive anxiety, difficulty tolerating the frustration caused by the non-fulfillment of desires, they provide maladaptive coping responses and tend to have a pessimistic view of the future (Carver \& Conor- Smith, 2010; Hutz \& Nunes, 2001).

Between optimism and the personality traits of extraversion and agreeableness, there were weak, but positive correlations, demonstrating that higher scores on these factors predict positive expectations for future events. Thus, optimistic individuals, tend to present more characteristics such as agreeableness, empathy, kindness, organization, and determination.

Finally, we may conclude that the Brazilian version of the LOT-R is an instrument that presents appropriate psychometric characteristics and that is ready for use in the Brazilian population. However, as mentioned before, the dimensionality of the scale is a very controversial issue in studies on optimism and pessimism. In order to clarify the conceptual and operational issues underlying this instrument, we suggest further studies with other kind of samples.

\section{References}

Anastasia, A. \& Urbina, S. (2000). Testagem psicológica. Porto Alegre: Artes Médicas.

Aspinwall, L. G. \& Taylor, S. E. (1992). Modeling cognitive adaptation: a longitudinal investigation of the impact of individual differences and coping on college adjustment and performance. Journal of Personality and Social Psychology, 61, 755-765.

Briggs, S. R. (1992). Assessing the Five-Factor Modelo $\mathrm{f}$ personality description. Journal of Personality, 60, 253-293.

Campbell, J. D., Chew, B., \& Scratchley, L. S. (1991). Cognitive and emotional reactions to daily events: the effects of self-esteem and self complexity. Journal of Personality, 59, 473-505.

Carver, C. S. \& Scheier, M. F. (1999). Optimism. In C. R. Snyder (Ed.), Coping. The psychology of what works. (pp. 182-204). New York: Oxford University Press.

Carver, C. S. \& Scheier, M. F. (2002). The hopeful optimist. Mahwah, NJ: Erlbaum.

Carver, C.S. \& Scheier, M. F. (2003). Optimism. In Lopez, S., \& Snyder, C. R. Positive psychology assessment: a handbook of models and measures (pp 75-89). Washington, DC: American Psychological Association.

Carver, C. S., Lehman, J. M., \& Antoni, M. H. (2003). Dispositional pessimism predicts illness-related disruption of social and recreational activities among breast cancer patients. Journal of Personality and Social Psychology, 84, 813-821.

Carver, S. C., Scheier, M. F., \& Segerstrom, S. C. (2010). Optimism. Clinical Psychology Review, 30, 879-889.

Carver, C. S., Pozo, C., Harris, S. D., Noriega, V., Scheier, M. F., Robinson, D.S., \& Clark, K. C.(1993). How coping mediates the effect of optimism on distress: a study of women with early stage breast cancer. Journal of Personality and Social Psychology, 65, 375-390.

Chang, E. C., D’Zurilla, T. J., \& Maydeu-Olivares, A. (1994). Assessing the dimensionality of optimism and pessimism using a multimeasure approach. Cognitive Therapy and Research, 18, 143-160.

Conselho Federal de Psicologia. Resolução CFP $N^{o}$ 016/2000 sobre a realização de pesquisa em Psicologia com seres humanos. 20 dez. 2000. Disponível em: < 
http:/ /www.pol.org.br/legislacao/doc/resolucao2000_16.doc. Acesso em: 17 jul. 2006.

Coopersmith, S. (1967). The antecedents of self-esteem. San Francisco: W. H. Freeman.

Crocker, J. \& B. Major (1989). Social stigma and selfesteem: the self-protective properties of stigma, Psychological Review 96, 608-630.

Curbow, B. Somerfield, M. R., Baker, E., Wingard, J. R., \& Legro, M. W. (1993). Personal changes, dispositional optimism and psychological adjustment to bone marrow transplantation. Journal of Behavior MedicineI, 16, 423-443.

Dember, W. N. \& Brooks, J. (1989). A new instrument for measuring optimism and pessimism: test-retest reliability and relations with happiness and religious commitment. Bulletin of Psychometric Society, 27, 365-366.

Di Paula, A. \& Campbell, J. D. (2002). Self-esteem and persistence in the face of failure. Journal of Personality and Social Psychology, 83, 711-724.

Fitzgerald, D. L., Tennen, H., Affleck, G., \& Pransky, G. S. (1993). The relative importance of dispositional optimism and control appraisals in the quality of life after coronary artery bypass surgery. Journal of Behavioral Medicine, 16, 25-43.

Heinonen, K., Räikkönen, K., \& Keltikangas-Järvinen, L. (2005). Self-esteem in early and late adolescence predicts dispositional optimism-pessimism in adulthood: a 21-year longitudinal study. Personality and Individual Differences, 39, 511-521.

Herzberg, P. Y., Glaesmer, H., \& Hoyer, J. (2006). Separating optimism and pessimism: a robust psychometric analysis of the revised Life Orientation Test (LOT-R). Psychological Assessment, 18, 433-438.

Hutz, C. S. \& Nunes, C. H. S. S. (2001). Escala Fatorial de Neuroticismo. São Paulo: Casa do Psicólogo.

Hutz, S. C. \& Zanon, C. (2011). Revision of the adaptation, validation, and normatization of the Rosenberg's Self-Esteem Scale. Avaliação Psicológica, 10(1), 41-49.

Hutz, C., Nunes, C. H., Silveira, A. D., Serra, J., Anton, M., \& Wieczorek, L. S. (1998). O desenvolvimento de marcadores para a avaliação da personalidade no modelo dos cinco grandes fatores. Psicologia: Reflexão e Crítica, 11(2), 395-411.
Jackson, L. M., Pratt, M. W., Hunsberger, B., \& Pancer, S. M. (2005) Optimism as a mediator of the relation between perceived parental authoritativeness and adjustment among adolescents: finding the sunny side of the street. Social Development, 14,(2), 273-304.

Laranjeira, C. A. (2008). Tradução e validação portuguesa do Revised Life Orientation Test (LOT-R). Universitas Psychologica, 7(2), 469-476.

Long, B. C. (1993). Coping strategies of male managers: a prospective analysis of predictors of psychosomatic symptoms and job satisfaction. Journal of Vocational Behavior, 42, 184-199.

Lopez, S. \& Snyder, C. R. (2003). Positive psychological assessment: a handbook of models and measures. Washington, DC: American Psychological Association.

Lyrakos, G. N., Damigos, D., Mavreas, V., Georgia, K., \& Dimoliatis, I. D. J. (2010). Translation and validation of the Greek Life Orientation Test-Revised. Soc. Indic. Res., 95, 129-142

Lyubomirsky. S., Tkach, C., \& Dimatteo, M. R. (2006). What are the differences between happiness and self-esteem? Social Indicators Research, 78, 363-404.

Marshall, G. N., Wortman, C.B., Kusulas, J. W., Hervig, L.K., \& Vickers Jr., R. R. (1992). Distinguishing Optimism From Pessimism: Relations to Fundamental Dimensions of Mood and Personality. Journal of Personality and Social Psychology, 62,1067-1074.

Myers, D. G. \& E. Diener (1995). Who is happy? Psychological Science, 6, 10-19.

Nunes, C. H. S. S., Hutz, C. S., \& Nunes, M. F. O. (2010). Bateria Fatorial de Personalidade (BFP). São Paulo: Casa do Psicólogo.

Pasquali, L. (2000). Psicometria: teoria dos testes psicológicos. Brasília: Prática.

Plomin, R., Scheier, M. F., Bergeman, C. S., Pedersen, N. L., Nesselroade, J. R., \& McClearn, G. E. (1992). Optimism, pessimism and mental health: a twin/ adoption analysis. Personality and Individual Differences, 13(8), 921-930.

Rosenberg, M. (1965), Society and the Adolescent Self-Image. Princeton, NJ: Princeton University Press.

Scheier, M. F. \& Carver, C. S. (1985). Optimism, coping, and health: assessment and implications of

Psico-USF, Bragança Paulista, v. 19, n. 3, p. 523-531, set./dez. 2014 
generalized outcome expectancies. Health Psychology, 4, 219-247.

Scheier, M. F. \& Carver, C. S. (1993). On the power of positive thinking: the benefits of being optimistic. Current Directions in Psychological Science, 2, 26-30.

Scheier, M. F., Carver, C. S., \& Bridges, M. W. (1994). Distinguishing optimism from neuroticism (and trait anxiety, self-mastery, and self-esteem): a reevaluation of the Life Orientation Test. Journal of Personality and Social Psychology, 67, 1063-1078.

Scheier, M. F., Carver, C. S., \& Bridges, M. W. (2001). Optimism, pessimism, and psychological well-being. In E. C. Chang (Ed.), Optimism and pessimism: implications for theory, research, and practice (pp. 189216). Washington, DC: American Psychological Association.

Smith, T. W., Pope, M. K., Rhodewalt, F., \& Poulton, J. L. (1989). Optimism, neuroticism, coping and symptom reports: an alternative interpretation of the Life Orientation Test. Journal of Social and Clinical Psychology, 56, 640-648.
Taylor, S. E., Kemeny, M. E., Aspinwall, L. G., Schneider, S. G., Rodriguez, R., \& Herbert, M. (1992). Optimism, coping, psychological distress and high-risk sexual behavior among men at risk for acquired inmunodefiency syndrome (AIDS). Journal of Personality and Social Psychology, 63, 460-473.

Trottier, C., Mageau, G., Trudel, P., \& Halliwell, W. R. (2008). Validation de la version canadienne-française du Life Orientation Test-Revised. Canadian Journal of Behavioural Science, 40(4), 238-243

Vautier, S. \& Raufaste, E. (2006). Configural instability of data from the Life Orientation Test- revised. Personality and Individual Differences, 40, 1511-1518.

Vera-Villarroel, P., Córdova-Rubio, N., \& Celis-Atenas, K. (2009). Evaluación del optimismo: un análisis preliminar del Life Orientation Test versión revisada (LOT-R) en población chilena. Univ. Psychol., 8(1), 61-68.

Recebido em: 25/09/2013

Reformulado em: 23/02/2014

Segunda reformulação em: 25/04/2014

Aprovado em: 24/05/2014

Nota dos autores:

Esta pesquisa foi financiada pelo CNPq.

Sobre os autores:

Micheline Roat Bastianello é psicóloga pela Universidade Federal de Santa Maria (2001), especialista em psicoterapia de crianças e adolescentes pela Universidade do Vale dos Sinos (2004) e mestre em Psicologia pela Universidade Federal do Rio Grande do Sul (UFRGS), 2011. Atualmente é doutoranda do Programa de Pós-Graduação em Psicologia da UFRGS.

Juliana Cerentini Pacico é psicóloga pela Universidade Federal de Santa Maria (2007), mestre em Psicologia (2011) e especialista em Psicologia Organizacional (2013) pela Universidade Federal do Rio Grande do Sul (UFRGS). Atualmente é doutoranda do Programa de Pós-Graduação em Psicologia da UFRGS.

Claudio Simon Hutz é psicólogo, mestre e Ph.D. pela University of Iowa (USA) e professor titular no Programa de Pós-Graduação em Psicologia da Universidade Federal do Rio Grande do Sul (UFRGS) é bolsista de Produtividade I-A do CNPq.

Contato com os autores:

Programa de Pós-Graduação em Psicologia da UFRGS

Rua Ramiro Barcelos, 2.600 - Bairro Santana

CEP: 90035-003 - Porto Alegre-RS, Brasil

E-mail: mbastianello@hotmail.com

Psico-USF, Bragança Paulista, v. 19, n. 3, p. 523-531, set./ dez. 2014 
